\title{
THE UNDERSTANDING OF CLASSICAL AND MODERN SCHOLARS ABOUT HADITH DOOMSDAY
}

\author{
Ach Baiquni \\ Syarif Hidayatullah State Islamic University (UIN) Jakarta \\ baiquni@uinjkt.ac.id
}

\begin{abstract}
This research is based on the recent phenomenon which some people assume that the Doomsday is closer. It is supported by some of the signs described in the hadith. The occurrence of civil wars in Arab countries, the construction of a magnificent mosque, high buildings and the rise of adultery serve as arguments that reinforce the presumption. Muslim scholars understand differently the hadith related to the signs of Doomsday. This study finds that the classical and modern scholars in understanding the various hadiths use language, sociology and science, depending on their background.
\end{abstract}

Keywords: Doomsday, Understanding Hadith, Scholar

\section{Introduction}

Some people assume that the apocalypse is getting closer. This statement is based on some signs described in the hadith. The signs contained in the hadith consist of: the occurrence of earthquakes, Euferat River dries up, the mark of immunity of Imam Mahdi, the war that occurred in the Middle East, the time passes fast, modern transportation and the collapse of moral values. (Jerry D. Gray, 2014: 5)

Hadiths about the doomsday are understood by all scientists based on their background. One who is expert in the field of science will understand the hadith with the approach of science, as well as others who is expert in the field of sociology will understand with his scientific study. Islah Gusmian said (2013: 9), "The approach found by the hermeneut cannot be separated from the process of interaction and the dialectic of writing with the world and its locality history."

This diversity of understanding will produce different conclusions about the doomsday. Some of them will conclude that the doomsday signs can be observed today, others will conclude that the doomsday signs cannot be found now. A scholar who concluding that doomsday signs can be seen today is Wishnu Sasongko $(2004,84)$ because of understanding the hadith of the appearance of Imam Mahdi and the war that occurs at the end of time. Vishnu understands that the emergence of al-Mahdi originated from the conflicts that occured in Iraq and Sham. These two countries were boycotted by Rum (America and Europe) and their allies. The boycott of Iraq causes the country not enough to get food, medicine and money, and then all cause many babies starve. It is natural that there is a claim that al-Mahdi emerged after the war of Iraq and Sham. In fact, there is an opinion which claims that al-Mahdi has descended namely Abu Bakar Al-Baghdadi, but such argument is denied by Micael Welss and Hasan Hasan in their book that (2015: 96) "ISIS uses the symbols of the end-time contained in the hadith in order to recruit its members, so they are known as the end-time troops promised by Prophet Muhammad in his Hadith."

This research is a literature research using descriptive approach by looking at how the scholars understand the hadith, examine the data in a comprehensive manner and then abstract it. The discussion in this paper will be discussed in several sections starting from the introduction, the approach of understanding the hadith, Hadith of doomsday as the case, the methodology of the scholars understanding the hadith of 
doomsday, the understanding approach of the hadith of doomsday in the present context.

\section{Hadith of Doomsday Signs as Case}

This discussion is not usually discussed in books that explain the signs of doomsday, but there are some Muslim scholars who deliver specific argument. In explaining the problem of understanding of the doomsday signs, one agrees to adapt it with scientific studies (science) or other social sciences. On the other hand, another disagrees because if hadith is analyzed with the present reality, it's afraid to be misunderstood.

Yusuf al-Qardawî (1998: 162) gives an explanation of the unseen nature in the hadith. He commented that the hadith about the unseen matter must be believed because it is a revelation that Allah revealed to Prophet Muhammad. Basically, the Prophet will not know the unseen thing if it is told by Allah such as described in QS al-Jin 26, "He is a God Who Knows the Unseen, and then He does not show anyone about the unseen. Except for the Apostle whom He hath directed, He hath set up guards (angels) before and behind." This verse explains that the Prophet himself did not know about the unseen yet.

The Prophet did not have the natural nature to know such things. Whereas, in another verse it is mentioned that Prophet does not know the unseen thing except something is given by Allah, so that the unbeliever of this case does not believe in the revelation.

The science of the doomsday is a science to be believed, but not to be commented, because the time of its occurrence is not known by all creatures and is not told by Allah, even Prophet and Angel do not know it. There are several verses that reinforce the argument that Allah alone knows the incident as contained in QS al-A'raf: 187, al-Ahzab: 63 and Thaha: 52. These verses describe the response of Prophet when he is asked about the doomsday time. Besides, the term shows implications that they are not fussy and do not ask so much.

The writer can understand al-Qardhawi's (1998: 198) argument that focuses to faith, not an understanding in judging the hadith of the doomsday, so it should not be understood by using the ratio and this can deceive the public.

As Badiuzaman Said Nursi and Harun Yahya (2001: 50) said that it is term of hadith which related to the events of the end of time then we can see the phenomenon in this decade shows its truth and validity although its quality and quantity are not valid (shahih).

Then, when someone finds several of the hadits that discuss the forecast of the doomsday signs, don't rush to conclude them. In fact, the emergence of interpretations of the hadith about the problem seeks to reveal the intent of the passage and dare to foresee the events illustrated by the hadith in light of recent phenomena such as Iraq's infancy to Kuwait, the collapse of the WTC, the outbreak of the Taliban and etc. Such interpretation can be wrong and can be true, but very sensitive because it has entered the area of faith. Imagine if the interpretation is not true, the shock and confidence of the truth of the Qur'an and hadits will happen. Many people will not believe its authentic. When they do not believe, they will dubious Islamic doctrine.

It is important readers of hadits obey a lot of points namely choosing the hadith carefully and knowing whether the hadith is valid or not, and not being hasty to conclude that the hadits is contextual with reality which is happening today. (Aslam Karso Rejo, 2003: 7, 8)

Muslih Abdul Karim (2005: 206) also argues basically the claim that al-Mahdi already existed has existed since ancient times when the Imamiyyah group has claimed 
that Muhammad Hasan bin 'Ali al-'Askari is Imam Mahdi as reported by Prophet. Nevertheless, the claim has been stunned by Muhammad Jari at-Thabari who said that the claim is false because person described in the hadith is not Hasan al-'Askari. Whereas, in the hadith al-Mahdi is Muhammad bin Abdullah, not Muhammad bin Hasan. In fact, some people named their child Muhammad al-Mahdi as did the Khalifah al-Makmun though it is far from the hadith implied by Prophet Muhammad.

While Sulaiman al-Saqqar (1990: 23) says, "The curiosity of humans about when doomsday will come and what are its signs is nature, but excessive efforts in predicting doomsday are not allowed, because scholars who attempt to research these will stumble with their problems, namely knowing better than Angel Gabriel and Prophet Muhammad."

\section{The Methodology of Classical and Modern Scholar in Understanding Hadith of Doomsday}

1. Approach to Understand Hadith of Doomsday

\begin{tabular}{|l|l|}
\hline SCHOLAR & $\begin{array}{l}\text { APPROACH IN UNDERSTANDING HADITH OF } \\
\text { DOOMSDAY SIGNS }\end{array}$ \\
\hline \multicolumn{2}{|c|}{ CLASSICAL } \\
\hline Ibn Katsir & \multicolumn{1}{|c|}{ Inductive Approach, Struggle with Other History } \\
\hline Ibn Hajar & $\begin{array}{l}\text { Struggle with Moral Message, Linguistic Approach, Sociological } \\
\text { Approach, Historical Approach, Inductive Approach }\end{array}$ \\
\hline Al-Nawawi & $\begin{array}{l}\text { Inductive Approach, Struggle with Moral Message, Linguistic } \\
\text { Approach, Sociological Approach, Historical Approach }\end{array}$ \\
\hline \multicolumn{2}{|c|}{ MODERN } \\
\hline $\begin{array}{l}\text { Zaghlul al- } \\
\text { Najjar }\end{array}$ & Approach to Science, Social Approach \\
\hline Harun Yahya & Approach to Science, Social Approach, Historical Approach \\
\hline $\begin{array}{l}\text { Wisnu } \\
\text { Sasongko }\end{array}$ & Social Approach, Historical and Deductive Approach \\
\hline Abu Fatiah & Social Approach, Historical Science and Deductive Approach \\
\hline
\end{tabular}

\section{Purpose of Understanding Hadiths of Doomsday Signs}

There are some motives or purposes of the Islamic scholars to understand the hadith of doomsday i.e. Imam Ibn Katsir (1991: 6) wrote in the preface of his book that he discusses and focus on the issue of fitan and the sign that occurred before the doomsday. Ibnu Katsir's book is to prove readers that what the Prophet Muhammad said is not the only story, but the fact that will be watched next time when the people will face the doomsday because Prophet Muhammad conveys something not based on his passions but he got a revelation from God. He has told us about earthquakes, slanders and so on, then the events can be witnessed in the period of Ibn Katsir and this requires us to believe and believe what Prophet said.

Imam al-Nawawî (1990: 27) gives the reason why he understood the hadith contained in Şahih Muslîm. Al-Nawawî wanted to summarize and explain very global content in order to be easily understood by people who read the book Şahih Muslîm. In addition, he wanted to explain easily in order that the content contained in the hadith was understood. Even if it is lengthening the explanation, it will amount to 100 volumes without repetition that is not too important. 
Ibn Hajar al-Asqalani (1991: 10) gives the reason why he wrote the book of Şahih Bukhari interpretation because he wanted to explain and convey in its content for people that want to explore the hadith.

As the request of the readers Abu Fatiah (2015: 7) wrote book detail about nubuwat-nubuwat (prophetic) which is currently happening at this time. This book is a book of other books that discuss the same issues equipped with facts and illustrations of events that occur today, it aims to make the readers believe more that the prophetic is a fact. This is truth of Rasulullah prophetic.

As for Wisnu Sasongka (2003: $\mathrm{x}$ ) in his book explains that the goal he wrote a book Armagedong Armagedong Following Zamansebagia War follows 1. To refute the orientalist assertion that "the end of the Muslims is only a utopia because Muslims are upset in everything including scientific and technological progress. 2. To open the eyes of the muslim so that they have a clear vision of the future that is knowing the final result is certain so it is not easy to vacillate with the atmosphere and circumstances. 3 . To add Islamic discourse, especially about futuristic as well as open as wide as possible discourse towards it.

Zaghlul al-Najjar $(2005,1)$ wants to prove that the truth of religion is absolute, while the scientific truth is relative, periodic and historical. In addition, al-Najjar wants to prove that the hadith fits and is in line with the development of modern science.

\section{Bid of Approach to Understand Hadith of Doomsday in Contemporary Context}

Understanding of hadith as a cultural product and the result of thought of human certainly need bid of approach that can make hadith as hudan linnas (hint for human), so writer offers approach which is similar to current context.

The authors cite the relevant approach of Salahuddin al-Idlibi to understand the hadith of doomsday is the inductive approach (i.e. by confirming with the verses of the Qur'an or corresponding hadiths), the approach of linguistics so that we can recognize the content of the text, and the human senses. Therefore, the hadith believed as the guidance of humans can be salih li kull al-zaman wa al-makan and the found understanding is not too imaginative. Practically, scholars understand the hadith too imaginative, so that it is irrelevant to the current context, whereas the hadith about doomsday has good moral message. Moreover, interpreter of the book can stand on the framework of understanding the hadith offered by Muhammad Salahuddin al-Idlibî (2000: 150), the writer suspects his understanding will be relevant with the life of society today.

\section{Conclusion}

Seven scholars are the reference in this study, three classical scholars and four modern scholars. They have their own methodology of understanding the hadith of Imam Ibn Kasir when understanding the hadith of doomsday with another meaningful history, to understand the hadith also by using the verses of the Qur'an and sometimes reinforced by his opinion, while his method is textual.

This model is also followed by Imam al-Nawawi but the difference is that alNawawi has begun to analyze with language approach, besides, al-Nawawi understands the hadith of doomsday either with its textual or contextual method according to the context of the hadith, if there is a hadith which requires detailed analysis and understanding, al-Nawawi only includes a history of the bush alone in order that the readers can understand by themselves. Ibn Hajar al-Asqalani understands the hadith by following his predecessor, but his approach has already begun to expand, the historical 
approach of the past becomes a tool for analyzing the hadith about the doomsday in order that person can describes the doomsday events as the picture of events occurring before Ibn Hajar born, the writer doesn't even find Ibn Hajar describing the incident when he was alive by relating it with the hadith of doomsday, and his method sometimes textual and contextual adjust to the content of his hadith.

The modern scholars in understanding hadith use various approaches, but they still refer to the works of Ibn Katsir, al-Nawawi and Ibn Hajar al-Asqalani. The four modern scholars: Muhammad Zaghlul al-Najjar understood the hadith with the approach of science (the research done by 20th century scientists), the historical approach, the contextual approach by following the understanding offered by al-Nawawi and Ibn Hajar, but not all the traditions understood by following the classical Islamic scholar approach, the writer only found in one hadith only. Then Harun Yahya understood the hadith by using various approaches namely sociology and science approach. His method is the textual because of focusing one meaning. In practicing Harun wants the hadith about the doomsday can be seen and reflected along with the progress of technology and transportation so that the way of understanding this hadith is rigid and impose the meaning of hadith textually in accordance with modern technological progress. Wishnu Sasongko used several approaches in understanding the hadith of the historical and sociological approaches. In practicing Wisnu understood the hadiths to be wounded with the war that occurred in the Middle East in 2000-now as the beginning of the forerunner of the Imam Mahdi. Wisnu recited the hadith and then explained by comparison with the chronology of war that is happening now with a picture of the hadith about the end-time war, so that the result of his understanding-still feels stiff.

Abu Fatiah al-Adnani understands the hadith about the doomsday signs by using various approaches such as: deductive approach, historical approach, science approach and sociology approach. al-Adnani in understanding the hadith refers to the classical books (written by Ibn Katsir, Ibn Hajar and al-Nawawi) and modern books (written by Harun Yahya) so that the way of understanding the hadith about the doomsday is sometimes the same as the scholar who became his reference, but Abu Fatiah based on the purpose of writing his book imposed the hadith of doomsday contextual with the present reality.

\section{References}

'Asqalanî, Al, Ahmad ibn 'Ali ibn Hajar, 1991. Fathul Barî Fi Syarhi Şahih al-Bukharî, Bairut: Dar al-Fikr

Adnani, al Abu Fatiah, 2008. Global Warning Sehuah Isyarat Dekatnya Akhir Zaman Dan Kehancuran Dunia, Surakarta: Granada Mediatarha,

al-Idlibi, Salahudin Ibn Ahmad, Manhaj Naqd Matan Inda Ulama al-Muhadisin

Gusmian, Islah, 2013. Khasanah Tafsir Indonesia, Yogjakata: LKiS,

Ibn Katşı̆r, 1990. Al-Nihâyat Fı̆ al-Fitân Wa Malahimi, Bairut; Dar al-Kutub al-Ilmiah

Gray, Jerry D. 2014. Hari-Hari Terakhir Dunia The Final Chapter, Penerjemah Muhammad Arief Indarjo, Depok: Sinergi,

Karim, Muslih Abdul, 2005. Isa \& al-Mahdi, Depok: Gema Insani,

Karso Rejo, Aslam, 2003. Kiamat diambang Pintu, Sukoharjo: an-Nuur Press,

Najâr, al Zaghlul Raghib, 2007. Al-I'jaz al-Ilm Fi al-Sunnah al-Nabawiah Kairo: Nadh Mesr,

Qardhawi, al- Yusuf, 1998. al-Qur'an berbicara Akal dan Ilmu Pengetahuan, Peneremah Abdul Hayyie al-Kattani dkk Jakarta: Gema Insani Press,

Sasongko, Wisnu, 2004. Armagenddon Peperangan Akhir Zaman, Jakarta: Gema Insani press 
Syaqâr, al Umar Sulaimân Abd Allah, 1991. al-Qiyâmah al-Sugrâ, Aman: Dar alNafâis,

Weiss, Michael dan Hassan Hassan, 2015. Isis The Inside Story, penerjemah Tri Wibowo BS Jakarta: Prenadamedia Group

Yahya, Harun, 1994. Signs Of The Last Day, Turki: Global Publication, 